\title{
Alternative Voices, Alternative Spaces: Counterhegemonic Discourse in the Blogosphere
}

(Final Submitted Version)

\section{Dr Deborah Gabriel | Bournemouth University}

Cite this work as follows:

Gabriel, D. (2015) Alternative Voices, Alternative Spaces: Counterhegemonic Discourse in the Blogosphere; in Media, Margins and Civic Agency, (eds.), Thorsen, E; Jackson, D; Savigny, H; \& Alexander, J. London: Palgrave Macmillan.

\section{Abstract:}

In 21st-century Britain, racial inequality remains deeply embedded in the fabric of society (Institute for Public Policy Research, 2010), and people of colour remain at the margins of the mainstream media that often perpetuate inequalities through misrepresentation or exclusion. This chapter examines how blogs are used by African Caribbean people as a discursive medium through which raced and gendered identities are contested, reconfigured and enacted within the blogosphere. Hailed as a revolutionary, democratic space, the blogosphere also maintains raced and gendered inequalities found offline and reproduces unequal power relations (Cammaerts, 2008; Kellner, 2000; Papacharissi, 2002; Schradie, 2012). Despite such limitations, as this chapter highlights, the blogosphere is still appropriated as a medium for selfrepresentation to cultivate symbolic power through their own constructions of Black identity. 


\section{Introduction}

In $21^{\text {st }}$ century Britain, racial inequality remains deeply embedded in the fabric of society (Institute for Public Policy Research, 2010) and the media is a key site for on-going struggles against hegemony (Bailey et al, 2008; Downing, 2001; Cammaerts, 2008). Women and people of colour remain at the margins of the mainstream media that often perpetuate inequalities through misrepresentation or exclusion. Black women are frequently constructed through the dominant discourse of 'the angry Black woman' (Isokariari, 2013) and measured by European standards of beauty (Collins, 1990) that render them invisible. Black men continue to be associated with criminality and are rarely represented beyond the stereotype of sporting hero (Ferber, 2007). This chapter examines how blogs are used by African Caribbean people as an assertive strategy, tool of resistance against racial oppression and resistance to misrepresentation and exclusion in the mainstream media. It reveals how the motivation and gratification of African Caribbean bloggers are driven by a complex set of factors linked to issues of race and representation that stem from feeling voiceless, invisible and marginalised within UK society. While hailed as a revolutionary, democratic space, the blogosphere maintains raced and gendered inequalities that exist offline and reproduces unequal power relations (Cammaerts, 2008; Kellner, 2000; Papacharissi, 2002; Schradie, 2012). However, as this chapter reveals, African Caribbeans still appropriate the blogosphere as a medium for self-representation to cultivate symbolic power through their own constructions of Black identity. While there is a growing body of research on the blogosphere, the use of blogs by people of colour in the UK is an under-developed area of inquiry. This chapter expands the current literature by highlighting how Black Britons engage with blogs in ways that differ from the White majority population. 


\section{Methodology}

The research on which this chapter is based is approached through the theoretical frameworks of alternative media and critical race theory (CRT), and the conceptual framework of uses and gratifications theory. Alternative media practice can be defined as non-mainstream, radical and participatory (Atton, 2001; Hamilton, 2000), while a key purpose of CRT is centring the Black voice and the Black experience (Delgado \& Stefancic, 2001; Hylton, 2012). In this study this is achieved through the constructed narratives of the bloggers in their in-depth interviews, which allows them 'to speak in a culturally authentic, socially meaningful and politically powerful voice' (Aldridge, 2000: 103). As Milner (2007: 391) argues: 'From critical race theory perspectives, knowledge can and should be generated through the narratives and counter-narratives that emerge from and with people of colour.' Uses and gratification theory aims to explain why people use certain types of media and the psychological needs that motivate their media use (Chung \& Kim, 2008), although it is not without limitations. There is a tendency to assume the existence of a universal mass media with common values, rather than acknowledge the diversity of media audiences in terms of class, race, gender and other factors (Morley, 1992). This chapter is based on a study involving in-depth interviews with 30 African Caribbean bloggers based in the UK, of which 26 are women and 4 are men, sourced through accidental and random sampling. The interviews were conducted in 2012 both face-to-face at the British Library and via telephone. Thematic data analysis was used as an inductive approach to identify key themes emerging from the data which will be discussed in this chapter.

\section{Motivation}


Previous studies have found that bloggers are motivated by both intrinsic and extrinsic factors (Nardi et al, 2004) and that motivation for blogging is strongly linked to the gratification from writing blogs (Liu et al, 2007). The findings of this study confirm that bloggers are motivated by a combination of intrinsic and extrinsic factors. While consistent with other studies, the uniqueness of the findings lie in motivations linked to identity and life experiences as a racialised minority group in UK society. These have been conceptualised within the emerging themes of voice, visibility and empowerment.

\section{Voice and visibility}

For some of the bloggers, the desire to have a voice in the public domain is an intrinsic motivation linked to a love of writing and sharing views, perspectives and experiences with an audience. However, for some of the participants, the motivation to blog is driven by a complex set of extrinsic factors linked to issues of race and representation that fuel a desire to be seen and heard in the public domain through their own constructions of identity. Isaac, a 35-year old sports blogger explains his frustrations with the media as a major motivation for starting a blog:

The media wants to cover what they want to cover about a certain race, portray a race as dumb or stupid or ignorant or illiterate or incapable of putting two words together or just complete criminals.

He turned to the blogosphere as an alternative space to challenge what he perceives as negative representations of African Caribbean people: '...I'll create my own audience and I'll create my own sort of media and through that I'll build up supporters along the way. That's how I got inspired, by being marginalised.' For Isaac, people with racialised identities are subject to 
negative stereotyping in the media and there is little interest among journalists in reporting the positive activities of ordinary Black men who do not fit a particular stereotype: 'Unless I'm a gangster or some sort of superstar they're ...not interested in what the man on the street has to say.' In using his blog as a medium to develop his own audience whom he cultivates as 'supporters', he adopts an approach that is radical in orientation; centred on challenging negative stereotypes of Black identity; and is a process of self-representation that denotes a 'new politics of representation' (Gabriel, 1998:17). In this regard, blogs can be viewed as a tool of resistance against racial oppression.

The perception of being excluded from the public domain is articulated by some of the female participants, for whom voice and visibility are powerful motivations for blogging. Nancy, a 33-year-old career and lifestyle blogger explains:

I was really fed up with what I thought was the misrepresentation of Black people in the mainstream. I just felt as a mum of three... where are all the positive role models; where is the inspiration, where is the voice really?

For Nancy, the exclusion of Black mothers as positive role models and her perception of 'misrepresentation' in the mainstream media lead to a sense of invisibility and voicelessness. These feelings motivated her to start a blog: 'My initial aim was to inspire, to show that Black people do more than what the mainstream likes to present.' Similar sentiments are expressed by Chioma, a 48-year old woman who writes about race, gender and politics:

I'm a UK African woman. I felt very invisible and a sense of voicelessness...voiceless in a society that doesn't hear me. I guess 
that having the blog was part of me using my voice. That's the reason I wanted to go with it really, to have that UK African womanist presence on the web.

It is important to note the self-identification in demographic, ethnic, cultural and social terms. African womanism is an African-centred strand of feminist ideology that rejects Black feminism as an offshoot of (White) feminism and which does not regard Black men as adversaries but subject to the same oppression as Black women (Hudson-Weems, 2004). Chioma's reference to being voiceless and invisible therefore relates to her self-defined identity as an African womanist in the UK. Her extrinsic motivation is self-representation and her blog allows her to negotiate and reconfigure her identity. The invisibility of Black women has been raised by many feminist writers, including Collins (1990) and hooks (2000), articulating the marginalisation of Black women. More recently, the term intersectional invisibility has been discussed in relation to Black women as individuals with multiple subordinate identities not regarded as being emblematic of women (a status reserved for White women), or of Black people, a status conferred upon Black men (Espinosa, 1994).

Black women are also rendered invisible in the mainstream media by being excluded from everyday representations of women. Nadine, a 31-year old wedding and bridal blogger, as a bride-to-be felt that Black women were absent as brides both in print magazines and on the web and this invisibility was her main motivation for starting a blog: 'I don't think I saw one Black model in the magazines...I would flick through pages and pages and not see one Black bride to be.' The exclusion of particular groups within the public sphere has been conceptualised as 'symbolic annihilation' (Gerbner, 1972). Tuchman (1978) argues that symbolic annihilation of women occurs through 
the media's constant exclusion, trivialising and devaluing of women, diminishing their status in society. More recently, Coleman \& Yochim (2008) have explored the 'symbolic annihilation of race'. The symbolic annihilation of Black women in the mainstream media as a consequence of intersectional invisibility is not necessarily remedied in the blogosphere as gender inequalities in the blogosphere do exist (Chen, 2011; Gregg, 2006; Harp \& Tremayne 2006; Herring et al 2004; Pedersen, 2008). However, by utilising blogs as a strategy for voicing, Black women are able to experience discursive power on the internet.

Extrinsic motivations for blogging linked to issues of race and representation demonstrate how blogs are used as a socially interactive medium through which racialised and gendered identities are contested, reconfigured and renegotiated. The concept of voice and visibility in terms of the motivations of these participants represents a desire to harness the discursive power of the internet to facilitate self-representation and participation within the public sphere.

\section{Empowerment}

Empowerment refers to 'a multi-dimensional social process' that 'fosters power in people for use in their own lives, their communities and in their society by acting on issues they define as important' (Page \& Czuba, 1999). As a motivational construct, empowerment can emanate from a sense of powerlessness, 'an intrinsic need for self-determination' (Conger \& Kanungo, 1988: 473) or self-efficacy (Bandura, 1977). Blogs can act as a medium for selfrepresentation and a mechanism for constructing an assertive voice, generating visibility and engendering empowerment through enhanced selfefficacy. Psychological empowerment through blogging can emerge from 
feeling part of a community that has a strong collective voice leading to increased confidence and assertiveness (Stavrositu, 2007). Women can gain psychological empowerment via blogging through a sense of community and a sense of agency, defined as the perception of a 'competent, confident and assertive voice' (Stavrositu \& Sundar, 2012: 371). Previous studies suggest that African women use the blogosphere to promote women's equality and empowerment through personal expression and social interaction (Somolu, 2007), and that the internet functions as a discursive space where marginalised groups can gain a sense of empowerment by developing successful voicing strategies (Mitra \& Watts, 2002). A small number of female participants use blogs as a medium for promoting business and enterprise. Jennifer, a 28-year old business blogger, runs a marketing agency and was motivated to start a blog 'to constantly have that voice' and 'to connect with other people'. The desire to have an assertive voice can be seen as a tool for generating a sense of authority and credibility as a business woman in a competitive marketplace.

A small number of female participants express a clear motivation for empowering others. Nadine devotes part of her blog to promoting small businesses and, though not exclusively owned by Black proprietors, the majority featured mostly serve Black communities: 'It's giving them a voice, free promotion and one of my most popular posts is where l've listed loads of African Caribbean wedding caterers.' The desire to showcase Black businesses denotes a motivation to empower others and self.

\section{Gratification}

Previous research suggests that gratification from writing blogs is linked to factors such as emotion management, life documenting and discussion within overall themes of process, content and social gratification (Sepp et al, 2007). 
Other studies have linked self-expression as a major gratification and social interaction to a lesser degree (Papacharissi, 2007). The findings of this study reveal that voice, knowledge-sharing, knowledge acquisition and social interaction are the primary gratifications from blogging.

\section{Voice}

For some of the participants, gratification is linked to complex forms of cultural expression. For example, Grace, a 35-year old creative writing blogger, confirms that what she most enjoys about blogging is:

Definitely getting my voice across, whoever cares, but I think I've got an opinion on something that I feel should be shared. It's kind of educating through humour; it's kind of getting points across with a bit of tongue-in-cheek.

Voice is explicitly expressed here, but also implicit in the above statement is self-expression, giving her opinion on issues, and educating readers. Later in the discussion she reveals that her sense of gratification is directly linked to the nature of the content she posts, described as:

Our experiences in Britain and being Black people. I think there are things we need to know about our history and culture and instead of beating people over the head with it, which sometimes I feel like I do, letting people laugh along with it as well as learning something.

The sense of gratification is further increased through receiving positive feedback; either through comments directly on the blog or where the article is shared on social media platforms as articulated through her narrative: 'What I relish most is when posts get a reaction and people start talking and take it off 
on their own. I think that's the best reward, then it's doing what it's meant to do.'

These examples demonstrate the interconnectedness between motivation and gratification in relation to voice as the primary factor. Although not explicit in their narratives, it is evident that positive affirmation of the blogger's efforts to represent the interests of African Caribbean people within the blogosphere leads to increased self-efficacy. This is particularly the case when the content is centred on issues around being Black in UK society. Increasingly, citizen engagement is directed more towards issues that affect the everyday lives of individuals and less influenced by formal political processes (Breindl, 2010). Consequently, the African Caribbean bloggers in this study engage in political thought and action through the pursuit of personal interests and lifestyle choices rather than through traditional political structures.

\section{Knowledge sharing}

Knowledge-sharing has been sub-divided into three distinct areas: experiential knowledge, professional knowledge and 'Black knowledge', defined here as the dissemination of information that highlights the contribution of African Caribbean people to the knowledge economy. The term 'experiential knowledge' is used here in relation to experiential learning theory, defined as 'the process whereby knowledge is created through the transformation of experience' (Kolb, 1984:41). A dimension of experiential knowledge that has emerged from experiential learning theory that has particular relevance to blogging is 'conversational learning' (Baker et al, 2002). This is based on the premise that people learn from each other to create new knowledge through the medium of conversation. Conversations are conceptualised as social experiences that generate new ways of seeing the world. The two dimensions 
of conversational learning involve personal knowledge, acquired through personal experiences, and social knowledge which emerges from ideas generated through texts and experiences, and is shared in conversations. Blogs, with their interactive elements of commenting, linking and sharing via social media and orally, can function as a conversational space and medium for learning and generating new knowledge. Odera, a 27-year old fashion blogger, makes an observant distinction between professional knowledge and experiential knowledge:

For me it's not so much about expertise but experiences. When I say I share my knowledge and expertise it's more about me sharing my experiences and hoping that it will help other people who are going through the same thing.

Lisa, a 33 year-old who blogs on social issues, is a qualified counsellor and although she no longer works in this profession, she uses her blog as a platform 'where I can use my knowledge in counselling to intertwine and weave with social issues and current trends'. The knowledge she imparts on her blog is self-defined as professional:

I class myself as a counsellor not confined to the counselling room. Just because I'm not counselling one-to-one does not mean I'm not a counsellor. I've got a bag of knowledge and I'm still using it in an everyday way.

For some participants, gratification is linked to sharing Black knowledge. Tracy, a 50 year-old creative writing blogger, works as a marketing director and writes a blog focused on books and literature. She says: 'All the books that I write about are Black fiction, Black writers, whether they're from Africa or the USA, 
Europe or the continent itself.' The purpose of the blog is to encourage and stimulate engagement with African and Caribbean literature and to promote the work of Black writers. Describing her level of gratification, she explains:

I like sharing what I've found out with other people, I think that's the main thing. People do tell me they enjoy it; now and then I get comments and things. It's nice to know that people like what I have to say about $X Y$ book or be interested in the interviews.

Luther, a 43-year old former journalist has carved a niche within the blogosphere as a social commentator and uses his blog to '[show] off my knowledge and expertise on the topic of Black music and popular culture...' Artistic freedom, feedback and interaction contribute to the sense of gratification:

I actually prefer blogging now to the journalism I used to do because I have a lot more freedom, I can write about whatever I want. The other great thing about blogging is the feedback. I very rarely got feedback when I was doing print journalism but now with the blog I get online feedback.

It can be argued that sharing Black knowledge is a political act, even if the content is not a direct critique of racism, but focused on celebrating and promoting Black literature and music. Power can be defined as having an effective voice-the capacity to advance one's view of the world and to define one's place within it as an active participant (Aldridge, 2000; Couldry, 2010). By promoting Black music and literature these bloggers are claiming a representational space within the public sphere and fulfilling a basic human need to be seen and heard (Couldry, 2010). 


\section{Knowledge acquisition}

The acquisition of knowledge gained through the process of constructing a blog post is part of the cycle of experiential (Kolb, 1984) and conversational learning (Baker et al, 2002). While bloggers generate knowledge within and beyond the blogosphere that informs others, they simultaneously undertake research for particular topics they write about. For some participants, gratification is produced through the act of informing and educating others, while on another level it occurs through the process of learning and conducting research. Mitchell, a 44 year-old who blogs on current affairs and race is 'very interested in the media, in journalism and current affairs' and gets a sense of satisfaction from the research process:

Researching can be quite interesting because I think there's an onus on you to do a little bit of homework when you write a blog. I think there's a duty to add a bit of research where you can because I think when people read a blog they expect a certain degree of expertise. Personally I find that interesting and fascinating in itself.

For Gloria, a 27-year old arts and culture blogger who seeks to highlight Black designers on her blog, the acquisition of knowledge relates to personal knowledge - one of the dimensions of conversational learning (Baker et al, 2002). In this instance, knowledge represents a journey of self-discovery:

I found it difficult to place myself one, as a designer and then two as a Black person. I think the blog is kind of hinting to the fact that what is being Black? That you wear African clothes and you speak with an accent?

Her gratification occurs through acquiring the knowledge that: 
It's discovering or almost promoting that Black isn't necessarily one thing even though we all come from the same place we're all dispersed around the world so all our influences, even though they're inherently African they all have different meanings.

\section{Social interaction}

Fumi, a 29-year old creative writing blogger began writing blogs as an online journal which eventually developed into a fictional series featuring Nigerian characters. In terms of gratification, feedback is the primary factor:

Just getting that feedback, getting the response, getting comments, that's something blogging does that nothing else can do...that's a very good buzz I get from blogging.

While feedback is explicitly stated, there is an underlying link to social interaction through engagement between blog authors and their audiences. Expressing similar sentiments, Isaac says:

Some of it is ego-driven. When you're blogging and you see one person following you, two people following you, three people following you and it goes on it encourages you to write more. When you blog and push that one button and it's going all around the world. Nothing more fulfilling than to see that someone says well done.

Charmaine, a 32-year old dating and relationships blogger, writes posts about her dating experiences as a Black woman in the UK and also cites interaction as the main form of gratification: 
I enjoy the interaction directly with the readers. Mine tend to be dating stories so people tend to connect more with them and they relate their stories back so there's a lot more interaction in my type of blogging than other types of blogging.

These narratives, while demonstrating the importance of social interaction to the bloggers also connect to the overarching themes of voice and visibility. Feedback and followers provide a form of validation that their blogs serve a useful purpose in informing and engaging audiences within and beyond Black communities.

\section{Conclusion}

Existing research acknowledges a cultural shift towards personalised political activity (Bennett \& Segerberg, 2011; Breindl, 2010) and the use of blogs for discursive activism (Moyo, 2011; Shaw, 2011; Steele, 2012). While this chapter complements current literature on the use of blogs as counterhegemonic practice, it offers new levels of understanding within a Black British context of the ways in which African Caribbeans use blogs to mediate against racism and marginalisation within UK society. The findings demonstrate a common understanding among the participants that race influences their world view based on their histories and experience. In addition to the use of blogs as counterhegemonic practice, they function as a medium for developing subjectivity by exploring what it means to be an African Caribbean man or woman in UK society.

The blogosphere is a contradictory space that reproduces inequalities that exist within traditional media (Kellner, 2000) and helps maintain corporate media power while providing a platform for counterhegemonic practice (Fuchs 
\& Sandoval, 2010). Despite these limitations, the blogosphere remains an important medium for discursive activism and discursive empowerment. The significance of voice in the findings links to Bourdieu's (1989:20) concept of symbolic power. Thus it can be argued that the blogosphere provides a platform 'for symbolic struggles over the power to produce and to impose the legitimate vision of the world' which can take the form of 'representation, individual or collective'.

\section{Bibliography}

Aldridge, D. (2000). On Rand Culture: Beyond Afrocentrism, Eurocentrism to Cultural Democracy, Sociological Focus. 33(1), 95-107

Atton, C. (2001.) Alternative Media. London: Sage.

Bailey, O., Cammaerts, B., and Carpentier, N. (2008). Understanding Alternative Media. Maidenhead: Open University Press.

Baker A., Jensen, P.J., and Kolb, D.A., (2002). Conversational Learning: An Experiential Approach to Knowledge Creation. Westport, CT: Quorum Books.

Bandura, A (1977). Towards a Unifying Theory of Behavioural Change, Psychological Review. 84 (2), 191-215.

Bennett, W.L., and Segerberg, A., (2011). Digital Media and the Personalisation of Collective Action, Information, Communication \& Society. 14(6), 770 799

Bourdieu, P, (1989). Social Space and Symbolic Power, Sociological Theory. 7(1), 14-25.

Breindl, Y. (2010). Critique of the Democratic Potentials of the Internet: A Review of Current Theory and Practice, TripleC-Cognition, Communication, Co-operation. 8(1),43-59.

Cammaerts, B. (2008). Critiques on the Participatory Potential of Web 2.0., 
Communication, Culture \& Critique. 1(4), 358-377

Chen, G. M. (2011). Why Do Women Write Personal Blogs? Satisfying Needs for Self-Disclosure and Affiliation Tell Part of the Story, Computers in Human Behavior. 28. 171-180.

Chung, D. S., and Kim, S., (2008). Blogging Activity Among Cancer Patients and Their Companions: Uses, Gratifications and Predictors of

Outcomes, Journal of the American Society for Information Science and Technology. 59(2), 297-306.

Coleman, R. R., and Yochim, E.C., (2008). The Symbolic Annihilation of Race: A Review of the" Blackness" Literature, Perspectives. 1-11

Collins, P.H. (1990). Black Feminist Thought: Knowledge, Consciousness and the Politics of Empowerment, New York: Unwin Hyman.

Conger, J.A., and Kanungo, R.N. (1988). The Empowerment Process: Integrating Theory and Practice, The Academy of Management Review. 13 (3), 471482.

Couldry, N. (2010). Why Voice Matters: Culture and Politics after Neoliberalism, London: Sage

Curran, J., Fenton, N., and Freedman, D. (2012). Misunderstanding the Internet. Oxford: Routledge

Dahlberg, L. (2007). Rethinking the Fragmentation of the Cyberpublic: From Consensus to Contestation, New Media \& Society. 9(5), 827

Delgado, R., and Stefancic, J. (2001). Critical Race Theory: An Introduction. USA: Temple University Press.

Downing, J. (2001). Radical Media: Rebellious Communications and Social Movements, Canada: Sage.

Eibach, R.P., and Purdie-Vaughans, V. (2008). Intersectional Invisibility: The Distinctive Advantages and Disadvantages of Multiple Subordinate 
Group Identities, Sex Roles. 59, 377-391.

Espinosa, L. (1994). Multi-identity: Community and Culture, Virginia Journal of Social Policy and the Law, 2(23)

Ferber, A.L. (2007). The Construction of Black Masculinity: White Supremacy Now and Then, Journal of Sport and Social Issues. 1(31), 11-24

Fuchs, C., and Sandoval, M. (2010). Towards a Critical Theory of Alternative Media, Telematics and Informatics. 27(2), 141-150.

Gabriel, J. (1998). Whitewash: Racialised Politics and the Media, London: Routledge.

Gerbner, G. (1972). Violence in Television Drama: Trends and Symbolic Functions, In G.A.Comstock., and E. Rubinstein (eds) Television and Social Behaviour 1 Content and Control. Washington DC: US Government Printing Office,

Gregg, M. C. (2006). Posting with Passion: Blogs and the Politics of Gender, In Bruns, A., and Jacobs, J., (Eds) Uses of Blogs. Brisbane: Peter Lang, 151160

Hamilton, J. (2000). Alternative Media: Conceptual Difficulties, Critical Possibilities, Journal of Communication Inquiry. 24(4), 357-378

Harp, D., and Tremayne, M. (2006). The Gendered Blogosphere: Examining Inequality Using Network and Feminist Theory, Journalism \& Mass Communication Quarterly 83(2), 247-264

Herring, S. C., Kouper, I., Scheidt, L. A., and Wright, E. L. (2004). Women and Children Last: The Discursive Construction of Weblogs In, Gurak, L., Antonijevic, S., Johnson, L., Ratliff, C., and Reyman, J. (eds) Into the Blogosphere: Rhetoric, Community, and Culture of Weblogs. Retrieved from http://blog.lib.umn.edu/blogosphere/women_and_children.html hooks, B. (2000). Feminist Theory: From Margin to Center, London: Pluto Press. 
Hudson-Weems, C. (2004). Africana Womanism: An Overview, In D.P.Aldridge., and C,Young. (eds) Out of the Revolution: The Development of Africana Studies. Maryland:Lexington Books, 205-217

Hylton, K. (2012). Talk the Talk, Walk the Walk: Defining Critical Race Theory in Research, Race Ethnicity and Education. 15(1), 23-41.

Institute for Public Policy Research (2010). Recession leaves almost half young black people unemployed, finds IPPR. Retrieved from http://www.ippr.org/news-and-media/press-releases/recession-leavesalmost-half-young-black-people-unemployed-finds-ippr Isokariari, M. (2013). 28 September) How can the angry black woman stereotype be challenged? The Voice. Retrieved from http://www.voiceonline.co.uk/article/how-can-angry-black-woman-stereotype-bechallenged?utm_source=dlvr.it\&utm_medium=twitter

Kellner ,D. (2000). Habermas, the Public Sphere, and Democracy: A Critical Intervention, Perspectives on Habermas. 259-288. Retrieved from http://knowledgepublic.pbworks.com/f/Habermas_Public_Sphere_Dem ocracy.pdf

Kolb, D.A. (1984). Experiential Learning: Experience as the Source of Learning and Development. New Jersey: Prentice-Hall

Liu, S.H., Liao, H.L., and Zeng, Y.T. (2007). Why People Blog: An Expectancy Theory Analysis, Issues in Information Systems. 8(2), 232-37.

Milner, H.R. (2007). Race, Culture and Researcher Positionality: Working through Dangers Seen, Unseen and Unforeseen, Educational Researcher. 36(7), 388-400.

Mitra, A., and Watts, E. (2002). Theorizing Cyberspace: The Idea of Voice Applied to the Internet Discourse, New Media \& Society. 4(4), 479-498. Morley, D. (1992). Televison, Audiences and Cultural Studies. London: 
Routledge.

Moyo, L. (2011). Blogging Down a Dictatorship: Human Rights, Citizen Journalists and the Right to Communicate in Zimbabwe, Journalism Theory Practice and Criticism. 12(6), 745-760.

Nardi, B.A., Schiano, D.J., Gumbrecht, M., and Swartz, L. (2004). Why We Blog, Communications of the ACM. 47(12), 41-46.

Page, N., and Czuba, C.E. (1999). Empowerment: What Is It? Journal of Extension. 37 (5), 1-5

Papacharissi, Z. (2002). The Virtual Sphere: The internet as a Public Sphere, New Media \& Society. 4(1), 9-27.

Papacharissi, Z. (2007). Audiences as Media Producers: Content Analysis of 260 blogs, In Tremayne, M. (ed) Blogging, Citizenship, and the Future of Media, London: Routledge, 3-20

Pedersen, S. (2008). Now Read This: Male and Female Bloggers'

Recommendations for Further Reading, Participations. 5(2), Retrieved from

http://www.participations.org/Volume\%205/Issue\%202/5_02_pedersen .htm

Pole, A. (2005). Black Bloggers and the Blogosphere. Paper presented the Second International Conference on Technology, Hyderabad, India.

Schradie, J. (2012). The Trend of Race Class and Ethnicity in Social Media Inequality: Who Still Cannot Afford to Blog? Information, Communication \& Society. $15(4), 555-571$

Sepp, M., Liljander, V., and Gummerus, J. (2007). Private Bloggers' Motivation to Produce Content: a Gratifications Theory Perspective, Journal of Marketing Management. 27 (13-14), 479-1503.

Shaw ,F. (2011). (Dis)locating Feminisms: Blog Activism as Crisis Response, 
Outskirts. 24.

Somolu, O. (2007). Telling Our Own Stories: African Women Blogging for Social Change, Gender \& Development. 15(3), 477-489.

Stavrositu, C. (2007). Technologies of Psychological Empowerment: The Role of Agency and Community in Blogging. Unpublished doctoral thesis, Pennsylvania State University, Pennsylvania.

Stavrositu, C., and Sundar, S. (2012). Does Blogging Empower Women?

Exploring the Role of Agency and Community, Journal of ComputerMediated Communication. 17 (4),369-386

Steele, C.K. (2012). Blogging While Black: A Critical Analysis of Resistance Discourse by Black Female Bloggers. Selected Papers of Internet Research (12.0).

Tuchman, G. (1978). The Symbolic Annihilation of Women by the Mass Media, In Tuchman, G., Daniel, A.K., Benet, J. (eds) Hearth and Home: Images of Women in the Mass Media. Oxford University Press: New York, 3-38 